\title{
Law Enforcement of General Election Crime as An Effort To Establish A Just Election
}

\author{
Tony Hermawan \\ \{tohermawan95@gmail.com\} \\ Doctor of Law, Universitas Jayabaya, Jakarta, Indonesia
}

\begin{abstract}
The handling of general election violations is mainly related to law enforcement issues. Violations always occurred in every election in Indonesia. This normative juridical research was supported by empirical juridical research, in which secondary data consisting of primary, secondary and tertiary legal materials were analyzed. The results showed that the ideal concept of general election criminal offenses eradication is an effort uphold the justice in elections by solving institutional problems. To overcome these problems, Ius Constituendum, the formation of a new independent institution (Auxiliary Organ), namely the Election Criminal Enforcement Commission is needed. This institution holds the direct responsibility from the public. The Election Criminal Enforcement Commission is required to enforce the values of democracy and sovereignty. This institution can be established based on the law, and its headquarter should be in the capital cities of the state, province and district / city. Election Criminal Enforcement Commission is in-charge of carrying out inquiry, investigation and prosecution to avoid institutional problem. Further, the objectives of elections and regional elections can be properly achieved.
\end{abstract}

Keywords: General Election, Law Enforcement, Criminal Offense

\section{Introduction}

General elections in Indonesia can be understood as a means of manifesting Pancasila democracy [1]. The value of Pancasila as the basis of the state (staat fundamental norm) has a strong correlation with the election in Indonesia [2]. The fourth principle, "Democracy guided by the inner wisdom in the unanimity arising out of deliberations among representatives," endorses the principle of democracy, and therefore, through general elections, a system of power based on people's sovereignty dictated by the fourth principle is formed. One of the recurring problems in the General Election lies in the law enforcement itself. In terms of people's involvement, the implementation of direct general elections after the amendment of the 1945 Constitution of the Republic of Indonesia has a massive and positive value. However, the elections also have problems, namely the voters' and the candidates' morality [3]. The strong desire to gain power encourages candidates and their winning teams to use negative strategies in reducing the electability and acceptability of their opponents.

In practice, direct elections in Indonesia is inseparable from 4 important issues: ERRI or ethnicity, religion, race, and intergroup (Suku, Agama, Ras, dan Antargolongan-SARA), transactional politic, exploitation of previous legal cases, and the strong affiliation of the media to certain groups or the loss of media responsibility as an important instrument in democracy. Meanwhile, in the perspective of the electoral law, violations are classified into three types: administrative, criminal or election crimes, and ethical [4]. For realizing a direct, general, free 
secret, honest and fair Election, Law number 15 of 2011 on the Election Administration is formulated, and the definition of the implementation of the election lies in article 1 paragraph (5). Based on Law Number 7 of 2017 concerning General Elections, the General Election Supervisory Agency (Badan Pengawas Pemilihan Umum-Bawaslu) has the authority to supervise the fields of Administration, Election Crime, and Ethics. Furthermore, general election disputes are interpreted as a conflict between election participants and other participants or participants and organizers due to the General Election Commission (Komisi Pemilihan Umum-KPU) and its branches in the provincial regency and district levels [5].

The resolution of election disputes is synchronized with Law Number 7 of 2017. It is resolved by the General Election Supervisory Agency and its branch in the city, district, village, and abroad, and the field supervisors of polling stations no later than 14 days from the initial report or findings (Article 454). Further provisions regarding procedures for resolving election disputes are regulated in the General Election Supervisory Agency Regulation [6]. Election criminal violations and the pattern of settlement of election criminal offenses are in several electoral laws. Law Number 8 of 2012 differentiate criminal acts which is a violation and criminal acts, which is a felony and all the characteristics that accompany them. In addition, changes also occur in the arrangement of criminal provisions, such as elimination towards the minimum of criminal provisions [7]. According to the Election Special Committee (Panitia Khusus Pemilihan Umum--Pansus Pemilu), the elimination of this minimum criminal provision aims to deliver the principle of legal certainty and make it easier for judges to render decisions.

Electoral law cases in Indonesia are indisputable [8]. The implementation of direct elections with integrity and accountability has not been realized. In addition, the election violations described above indicate the poor quality of general elections in Indonesia. The complexity of general elections encourages election administrators, in this case, the Election Supervisory Body, to ensure an honest and fair election. As noted, one of the main conditions for democracy is the presence of a free and fair general election system [9]. There should be legal instruments to regulate the election process and protect organizers, candidates, voters, observers, and citizens from fear, intimidation, violence, bribery, fraud, and various debauchery that affect the election results [10]. An important breakthrough involves a collaboration of 3 institutions, especially when dealing with election-related crime resolution need to be established.

\section{Research Methods}

The study utilizes certain methods that include a normative juridical method that is supported by empirical means. It is also called doctrinal study as it aims to analyse the law as it is written and law that is rendered through a juridical process by the judge.

\section{Results and Discussion}

The legal basis of the involvement of the Centre of Integrated Law Enforcement (Sentra Penegakan Hukum Terpadu--Sentra Gakkumdu) is the existing law itself. There are significant changes related to the institutional strengthening of the Sentra Gakkumdu as an instrument for enforcing election law. In this context, Gakkumdu holds a central role because of its authority. In the regulation issued by the General Election Supervisory Agency Number 9 of 2018 
concerning the Centre of Integrated Law Enforcement, in Chapter I of General Provisions Article 1 (2), the Centre of Integrated Law Enforcement is defined as the main body against election criminal acts. It is composed of the General Election Supervisory Agency and its provincial, regency, and city level, Indonesian National Police, Regional Police, and/ or City Police, and Attorney General Office of the Republic of Indonesia and their adjunct bodies High Prosecutor Office and District Attorney Office.

In this case, a judiciary body possessing great power in determining the orientation of law enforcement would always be at the centre of public attention and scrutiny [11]. On another occasion, some experts believe that law enforcement is closely related to the criminal justice system. For instance, Barda Nawawi Arief argues that the criminal justice system is essentially identical to the criminal law enforcement system [12]. The criminal justice system is handling a criminal case that then takes legal action against the crime that starts from investigations, prosecutions in court, and eventually the execution of judicial decisions. As stated earlier, the tendency in analysing and processing a criminal election with Sentra Gakkumdu is included in the core of the discussion. From some of the research presented, a sectoral ego pattern relies on one particular unit that single-handedly runs the operation. This context will be closely related to how the Sentra Gakkumdu as a unit managing and achieving election law enforcement objectives and creating a dignified election [13]. On that occasion, the central issue is how to create synergy and institutional strength among the involved elements within the Sentra Gakkumdu.

As a complete and coherent unit, the General Election Supervisory Agency, the Attorney General Office, and the Police or Republic of Indonesia are initially the apparatuses of electoral law enforcement. However, there is an argument that excludes General Election Supervisory Agency as law enforcement. In addition to not mandated by the law, their position is merely in a supervisory capacity and does not have executorial rights to proceed with suspicions concerning election crimes. The adoption of this paradigm can be seen from the involvement of election supervisors who cannot oversee the process of investigation, investigation, prosecution, and the verdict of the panel of judges in court. The General Election Supervisory Agency is only given the authority to determine whether an act has violated the provisions of the Election Crime. This includes a joint decision between the police, the prosecutor's office, and the supervisory agency itself. In the next process, both the police and the prosecutor's office proceed to the criminal procedural law mechanism. On the same occasion, based on the case characteristic, it seems the supervisory agency is unable or not granted the authority or adequate space to become the "law enforcement" of election crimes. However, how if Sentra Gakkumdu is seen as an inseparable entity?

The Sentra Gakkumdu is only formed when the general election stage takes place and is dismissed once the election is over [14]. This pattern creates a recurring discontinuity that is counterproductive to transferring knowledge and transferring cases in the future. The pattern of poor transfer of knowledge occurs if the apparatus from the prosecutor's office and the police experiences a rotation or transfer. Lex specialis of election law enforcement, of course, requires an impeccable experience and track record. In a field considered a special law, installing professional personnel understanding the flow and pattern of handling such matters is necessary.

Concerning the weakness of the Sentra Gakkumudu, the state should have established a state-supporting organ called the Election Criminal Enforcement Commission (Komisi Penegakan Pidana Pemilu). The formation of this commission stems from the ineffectiveness of the police, the Attorney General Office, and the General Election Supervisory Agency in solving various problems of election criminal offenses in Indonesia. The concept of Sentra Gakkumudu in Indonesia is understood as a state support institution that figures in investigating, inquiring, 
and prosecuting every criminal election and regional election offender. Their stance reflects an independent state institution that is free from interference or bias. This is inseparable from the principles of democracy maintaining the values of people's sovereignty and the principles of elections aiming for honest and fair elections.

To anticipate the failure of the Sentra Gakkumudu as the state auxiliary organ, a mature and comprehensive institution should be designed. One form of anticipation is expressed by Firmansyah et al., which say that a new state institution must be based on the principles of constitutionalism, check and balances, integration, and benefit to the community. The legal framework that will be ingrained in the electoral regulations must be built by establishing clear provisions and protecting the interests of the right to vote for every citizen, including the rights of candidates and political parties as eligible participants. These protected rights are enshrined in the law.

It is undeniable that in contemporary studies of the implementation of democratic values, an election is absolute. A rigorous and complex process in the democratic process is an added value to improve the quality of democracy in Indonesia. However, procedural quality must be accompanied by the quality of the democratic substance as the core values of democracy themselves. Efforts to concretize the values of the substance of democracy or, in this case, specifically in the implementation of elections, need immediate attention, especially law enforcement of the criminal election law itself. Moreover, the effectiveness of law enforcement is inseparable from the 5 aspects. These are regulation (Law), law enforcement, facility, the community, and cultural factors. These aspects are certainly in line with what was conveyed by Lawrence Friedman that 3 important aspects influence law enforcement: legal substance, legal structure, and legal culture.

If the 5 aspects of Soerjono Soekanto and 3 of Friedman's thoughts on law enforcement are connected to the implementation of election criminal law enforcement, ideally, there should be no election criminal offenses because the normative legal aspects are firm and multifaceted. The three legal cultures of the community, in this case, of both election participants and the community as voters, would be decent, although encouragement is constantly necessary.

As one of the innovative steps in electoral law enforcement in the future, it is necessary to harmonize or codify the regulations for avoiding overlapping rules or double standards in the implementation of elections. The legal culture in the society is essential in the mindset of a clean election. Therefore, it needs to be stimulated or encouraged through innovative steps to make people feel obligated to contribute to every election. Finally, these innovative steps from all the aspects expressed by scholars are futile if there is no commitment to realize electoral law enforcement. Apart from regulations, legal structures, facilities and infrastructure, society, and legal culture, there should be a commitment to social tools engineering.

\section{Conclusion}

The ideal concept of resolving general election criminal offenses is an effort to realize the enforcement of electoral justice by overcoming institutional problems. In the effort to achieve a resolution, the Ius Constituendum is needed, namely the formation of a new institution that is positioned as an independent state supporting institution (Auxiliary Organ) by the name of namely Election Criminal Enforcement Commission (Komisi Penegakan Pidana Pemilu) that directly assume responsibility for the interest of the public. This institution functions to uphold democratic values and people's sovereignty. It can be formed through law and headquartered at 
the Capital city or in the province and city. As for its authority, its tasks are investigations and prosecutions to prevent institutional disharmony and assure ease of execution of the objectives of ideal elections.

\section{References}

[1] Eddyono, Luthfi Widagdo, 'The Constitutional Court and Consolidation of Democracy in Indonesia', Jurnal Konstitusi, 15.1 (2018) <https://doi.org/10.31078/jk1511>

[2] Elklit, Jørgen, and Palle Svensson, 'What Makes Elections Free and Fair?', Journal of Democracy, 8.3 (1997) <https://doi.org/10.1353/jod.1997.0041>

[3] Listyaningrum, Resty, Yosesrwan, and Khairani, 'Implementation of Integrated Law Enforcement Center (Gakkumdu) In TheHandling of Criminal General Election for 2019 in West Sumatera', International Journal of Multicultural and Multireligious Understanding, 7.2 (2020), 412-18

[4] Lustig, Doreen, and J. H.H. Weiler, 'Judicial Review in the Contemporary World- Retrospective and Prospective', International Journal of Constitutional Law, 16.2 (2018) <https://doi.org/10.1093/icon/moy057>

[5] Muchammad, Nur, and Munsharif Abdul Chalim, 'Analysis Of Criminal Liability Crime of Legislative Elections (Case Study Legislative Elections in Semarang)', Jurnal Daulat Hukum, 2.1 (2019) <https://doi.org/10.30659/jdh.v2i1.4210>

[6] Muhtadi, Burhanuddin, Vote Buying in Indonesia: The Mechanics of Electoral Bribery, Vote Buying in Indonesia, 2019

[7] Paramarta, Anggun, 'Judicial Mafia in Criminal Justice System and Its Countermeasure', Jurnal Hukum Novelty, 9.2 (2018) <https://doi.org/10.26555/novelty.v9i2.a11263>

[8] Prawira, Syailendra Anantya, and Amalia Diamantina, 'Election Violation and Election Law Enforcement in General Election in Indonesia', Jurnal Hukum Volkgeist, 4.1 (2019), 25-34

[9] Tauda, Gunawan, 'PEMAKNAAN PANCASILA SEBAGAI NORMA FUNDAMENTAL NEGARA', Humano: Jurnal Penelitian, 9.2 (2019) <https://doi.org/10.33387/hjp.v9i2.927>

[10] Walter, Annemarie S., and David P. Redlawsk, 'Voters' Partisan Responses to Politicians' Immoral Behavior', Political Psychology, 40.5 (2019) <https://doi.org/10.1111/pops.12582>

[11] Wartoyo, Franciscus Xaverius, and Benyamin Tungga, 'The Consept And Its Implementation Of Indonesian Legislative Elections Based On The Pancasila Democracy Perspective', Yustisia Jurnal Hukum, 8.1 (2019) <https://doi.org/10.20961/yustisia.v0ixx.13226> 